University of Nebraska - Lincoln

DigitalCommons@University of Nebraska - Lincoln

$5-1986$

\title{
DNA Methyltransferase Induced by PBCV-1 Virus Infection of a Chlorella-Like Green Alga
}

Yuannan Xia

University of Nebraska-Lincoln

James L. Van Etten

University of Nebraska-Lincoln, jvanetten1@unl.edu

Follow this and additional works at: https://digitalcommons.unl.edu/plantpathpapers

Part of the Plant Pathology Commons

Xia, Yuannan and Van Etten, James L., "DNA Methyltransferase Induced by PBCV-1 Virus Infection of a Chlorella-Like Green Alga" (1986). Papers in Plant Pathology. 116.

https://digitalcommons.unl.edu/plantpathpapers/116

This Article is brought to you for free and open access by the Plant Pathology Department at DigitalCommons@University of Nebraska - Lincoln. It has been accepted for inclusion in Papers in Plant Pathology by an authorized administrator of DigitalCommons@University of Nebraska - Lincoln. 


\title{
DNA Methyltransferase Induced by PBCV-1 Virus Infection of a Chlorella-Like Green Alga $\dagger$
}

\author{
YUANNAN XIA AND JAMES L. VAN ETTEN* \\ Department of Plant Pathology, University of Nebraska, Lincoln, Nebraska 68583-0722
}

Received 2 December 1985/Accepted 24 January 1986

\begin{abstract}
A DNA methyltransferase was isolated from a eucaryotic, Chlorella-like green alga infected with the virus PBCV-1. The enzyme recognized the sequence GATC and methylated deoxyadenosine solely in GATC sequences. Host DNA, which contains GATC sequences, but not PBCV-1 DNA, which contains $G^{\mathrm{m}}$ ATC sequences, was a good substrate for the enzyme in vitro. The DNA methyltransferase activity was first detected about $1 \mathrm{~h}$ after viral infection; PBCV-1 DNA synthesis and host DNA degradation also began at about this time. The appearance of the DNA methyltransferase activity required de novo protein synthesis, and the enzyme was probably virus encoded. Methylation of DNAs with the PBCV-1-induced methyltransferase conferred resistance of the DNAs to a PBCV-1-induced restriction endonuclease enzyme described previously (Y. Xia, D. E. Burbank, L. Uher, D. Rabussay, and J. L. Van Etten, Mol. Cell. Biol. 6:1430-1439). We propose that the PBCV-1-induced methyltransferase protects viral DNA from the PBCV-1-induced restriction endonuclease and is part of a virus-induced restriction and modification system in PBCV-1-infected Chlorella cells.
\end{abstract}

With the exception of the two Iridoviruses, frog virus 3 (21) and fish lymphocytosis disease virus (19), and human papillomavirus $(3,4)$, DNAs isolated from viruses that infect eucaryotes lack or contain few methylated bases $(5,6)$. In the two Iridoviruses about 20 to $22 \%$ of the cytosines exist as 5-methyldeoxycytosine $\left(\mathrm{m}^{5} \mathrm{dC}\right)$. We have recently discovered a number of large double-stranded DNA viruses that infect the unicellular, eucaryotic Chlorella-like green alga strain NC64A. These viruses contain significant quantities of $\mathrm{m}^{5} \mathrm{dC}\left(0.3\right.$ to $13 \%$ of the cytosines are $\left.\mathrm{m}^{5} \mathrm{dC}\right)$ in their genomic DNAs $(16,18)$. About half of these viral DNAs also contain $N^{6}$-methyldeoxyadenosine $\left(\mathrm{m}^{6} \mathrm{dA}\right)(1.5$ to $8 \%$ of the adenosines are $\mathrm{m}^{6} \mathrm{dA}$ ). Although nuclear DNA from the host Chlorella sp. also contains $21 \% \mathrm{~m}^{5} \mathrm{dC}$ and $0.6 \% \mathrm{~m}^{6} \mathrm{dA}$, some, if not all, methylated bases in the host DNA occupy different sequences from those in the viral DNAs (18). This suggests that these viruses encode DNA methyltransferase enzymes that methylate DNA sequences distinct from those methylated by the host enzyme(s).

Results presented in the preceding paper (22) demonstrate that infection of Chlorella strain NC64A by one of these viruses, PBCV-1, induces the synthesis of a restriction endonuclease enzyme. This restriction endonuclease recognizes the sequence GATC and cleaves DNA 5' to the G; however, the enzyme does not cleave $G^{\mathrm{m}} \mathrm{ATC}$ sequences. The present paper describes a DNA methyltransferase that appears after infection of Chlorella strain NC64A with PBCV-1. This methyltransferase specifically methylates deoxyadenosines in the sequence GATC.

\section{MATERIALS AND METHODS}

Growth and infection of alga. The production and purification of the viruses PBCV-1, NC-1A, NC-1D, SC-1A, SC-1B, IL-2A, and IL-3A and the growth of the host Chlorella strain NC64A on MBBM medium have been described previously $(16,17,22)$. Chlorella strain NC64A $\left(1 \times 10^{7}\right.$ to 2

\footnotetext{
* Corresponding author.

$\dagger$ Published with the approval of the Director as paper no. 7951, Journal Series, Nebraska Agricultural Experiment Station.
}

$\times 10^{7}$ cells per $\mathrm{ml}$ ) was infected with $\mathrm{PBCV}-1$ at a multiplicity of infection of 5 , and cells were collected by centrifugation and either used immediately or frozen at $-80^{\circ} \mathrm{C}$. Infection of Chlorella cells previously exposed to UV light has been described previously (22).

Enzyme extracts. Enzyme extracts were prepared by the same procedure used to extract the PBCV-1-induced restriction endonuclease described in the preceding paper (22). Briefly, cells were disrupted in $0.01 \mathrm{M}$ Tris hydrochloride (pH 7.9)-0.01 M 2-mercaptoethanol-50 $\mu \mathrm{g}$ of phenylmethylsulfonyl fluoride per $\mathrm{ml}$ in a Bronwill MSK homogenizer, and the homogenate was centrifuged at $10,000 \times g$ for 20 min; the supernatant was frozen at $-20^{\circ} \mathrm{C}$, thawed at $4^{\circ} \mathrm{C}$, and centrifuged at $16,000 \times g$ for $30 \mathrm{~min}$ (fraction 1 ). The following components were added per milliliter of supernatant: $0.5 \mathrm{ml}$ of denatured salmon sperm DNA at $5 \mathrm{mg} / \mathrm{ml}$ in $0.01 \mathrm{M}$ Tris hydrochloride ( $\mathrm{pH}$ 7.9), $0.001 \mathrm{M}$ EDTA, $0.6 \mathrm{~g}$ of polymer concentrate $(7 \%$ [wt/wt] dextran T500, 28\% [wt/wt] polyethylene glycol 6000 ), and $0.64 \mathrm{ml}$ of $4 \mathrm{M} \mathrm{NaCl}$. The samples were mixed for $5 \mathrm{~min}$ and then centrifuged for 10 min at $5,000 \times g$. The supernatant was dialyzed overnight against $0.01 \mathrm{M} \mathrm{KPO}_{4}(\mathrm{pH} 7.4)-0.5 \mathrm{mM}$ sodium EDTA-7 mM 2-mercaptoethanol-5\% (vol/vol) glycerol at $4^{\circ} \mathrm{C}$ (fraction 2$)$. The samples were either assayed for enzyme activity at this stage or diluted to $200 \mathrm{ml}$ with $0.01 \mathrm{M} \mathrm{KPO}_{4}(\mathrm{pH} \mathrm{7.4)}$ and chromatographed on a phosphocellulose (Whatman P11) column $\left(1\right.$ by $10 \mathrm{~cm}$ ) equilibrated with $0.01 \mathrm{M} \mathrm{KPO}_{4}$ buffer (pH 7.4). Protein was eluted stepwise with 5-ml portions of $0.01 \mathrm{M} \mathrm{KPO}_{4}$ (pH 7.4) containing $\mathrm{KCl}$ from 0 to $1.0 \mathrm{M}$ in 0.1 $M$ increments. Fractions of $1 \mathrm{ml}$ were collected, and the fractions containing enzyme activity $(0.3$ to $0.4 \mathrm{M} \mathrm{KCl})$ were pooled (fraction 3 ). Enzyme activity was precipitated with $70 \%\left(\mathrm{NH}_{4}\right)_{2} \mathrm{SO}_{4}$, taken up in $10 \mathrm{mM}$ Tris hydrochloride $(\mathrm{pH}$ 7.5)-100 mM KCl-0.1 mM sodium EDTA-1 mM dithiothreitol-500 $\mu \mathrm{g}$ of bovine serum albumin per $\mathrm{ml}-50 \%$ ( $\mathrm{vol} / \mathrm{vol}$ ) glycerol (fraction 4 ), and stored at $-20^{\circ} \mathrm{C}$.

DNA methyltransferase assays. DNA methyltransferase activity was assayed in $50-\mu \mathrm{l}$ volumes consisting of $50 \mathrm{mM}$ Tris hydrochloride ( $\mathrm{pH} 8.0$ ), $10 \mathrm{mM}$ sodium EDTA, $1 \mathrm{mM}$ dithiothreitol, $20 \%$ (vol/vol) glycerol, $2 \mu \mathrm{Ci}$ of $S$-adenosyl $\left[\right.$ methyl- $\left.{ }^{3} \mathrm{H}\right]$ methionine $(78 \mathrm{Ci} / \mathrm{mmol}$; New England $\mathrm{Nu}-$ 
TABLE 1. DNA methyltransferase activity in uninfected and PBCV-1-infected Chlorella cells

\begin{tabular}{|c|c|c|c|}
\hline \multirow{2}{*}{ Enzyme extracts from: } & \multicolumn{3}{|c|}{$\begin{array}{l}\left.\text { cpm of [methyl }-{ }^{3} \mathrm{H}\right] \mathrm{DNA} \text { transferred/ } \\
10 \mu \mathrm{l} \text { of enzyme }{ }^{a} \text { after incubation for: }\end{array}$} \\
\hline & $\overline{O H}$ & $1 \mathrm{~h}$ & $2 \mathrm{~h}$ \\
\hline Uninfected cells & 59 & 348 & 535 \\
\hline \multicolumn{4}{|l|}{ Infected cells (h p.i. ${ }^{b}$ ) } \\
\hline $\mathbf{0}$ & 77 & 466 & 587 \\
\hline 1 & 73 & 7,670 & 31,350 \\
\hline 2 & 65 & 13,113 & 65,630 \\
\hline 3 & 224 & 27,414 & 80,540 \\
\hline 4 & 188 & 34,057 & 94,586 \\
\hline
\end{tabular}

a Enzyme extracts (fraction 2) were prepared from an equal number of uninfected or PBCV-1-infected cells at the indicated times. Reaction mixtures $(50 \mu l)$ containing $2 \mu \mathrm{Ci}$ of $S$-adenosyl[methyl $\left.{ }^{3} \mathrm{H}\right]$ methionine, $3 \mu \mathrm{g}$ of unmethylated lambda DNA, and $10 \mu \mathrm{l}$ of enzyme extract were incubated at $37^{\circ} \mathrm{C}$ for the indicated times.

b.i., Postinfection.

clear Corp., Boston, Mass.), 1 to $3 \mu \mathrm{g}$ of DNA, and 20 to 30 $\mathrm{U}$ of enzyme extract. After incubation for $2 \mathrm{~h}$ at $37^{\circ} \mathrm{C}$, the reactions were stopped by adding $0.5 \%$ sodium dodecyl sulfate and $50 \mu \mathrm{g}$ of pronase (previously self-digested for 60 min at $37^{\circ} \mathrm{C}$ ). Methyl groups incorporated into protein and RNA were eliminated, and samples were processed as described by Jones and Taylor (9).

In some experiments, DNA methyltransferase was measured by its ability to protect substrate DNAs from digestion with bacterial restriction endonucleases or with the PBCV1 -induced restriction endonuclease (22). In these experiments, 15 to $20 \mathrm{U}$ of the methyltransferase enzyme were incubated with $1 \mu \mathrm{g}$ of DNA in $20 \mu$ l of the methylation assay mixture except that $S$-adenosyl[ methyl $\left.-{ }^{3} \mathrm{H}\right]$ methionine was replaced with $0.024 \mathrm{mM}$ of unlabeled $S$-adenosylmethionine. After incubating for $2 \mathrm{~h}$ at $37^{\circ} \mathrm{C}$, the samples were either heated to $65^{\circ} \mathrm{C}$ for $20 \mathrm{~min}$ to inactivate the enzyme or extracted with phenol-chloroform or both. The resultant DNAs were incubated with the appropriate restriction endonucleases, and DNA fragments were resolved by electrophoresis on $1.2 \%$ agarose gels as described previously (22).

One unit of DNA methyltransferase activity is defined as the amount of enzyme required to protect $1 \mu \mathrm{g}$ of lambda DNA for $1 \mathrm{~h}$ at $37^{\circ} \mathrm{C}$ from cleavage by the PBCV-1-induced restriction endonuclease.

Sources of DNAs. The host nuclear DNA and viral DNAs were isolated as described previously (18). Unmethylated pBR322 plasmid DNAs, either containing a 16-kilobase-pair BamHI PBCV-1 DNA insert (labeled B6) (plasmid pLG164) or without B6, were prepared by growing the plasmids in Escherichia coli GM2163 as described previously (18). This strain of $E$. coli, provided by Martin Marinus, lacks both $d a m$ and $\mathrm{dcm}$ methyltransferase activity (11). The resultant pLG164 plasmid DNA was restricted with BamHI, and the viral B6 DNA fragment was recovered from low-melting temperature agarose gels by repeated phenol and phenolchloroform extractions. Unmethylated lambda DNA was purchased from New England Nuclear Corp.

Other procedures. The DNAs were incubated with dam methylase (New England BioLabs, Inc., Beverly, Mass.) or restriction endonucleases according to the protocols provided by the suppliers or with a PBCV-1-induced restriction endonuclease (22). Restriction fragments were electrophoresed on $1.2 \%$ agarose gels.
Digestion of DNAs and analysis of the resulting deoxynucleotides by high-performance liquid chromatography were as described previously (14).

\section{RESULTS}

Increased DNA methyltransferase activity in infected cells. Enzyme extracts (fraction 2) were prepared from uninfected Chlorella cells and from cells at various times after PBCV-1 infection and assayed for DNA methyltransferase activity with unmethylated lambda DNA as a substrate. Uninfected cells contained a low level of DNA methyltransferase activity (Table 1). This was expected since the host nuclear DNA contains $21 \% \mathrm{~m}^{5} \mathrm{dC}$ and $0.6 \% \mathrm{~m}^{6} \mathrm{dA}$ (18). However, the methyltransferase activity increased dramatically after PBCV-1 infection.

Preliminary characterization of the DNA methyltransferase indicated that optimum activity was at $37^{\circ} \mathrm{C}$ and a pH of 7 to 8 . Heating the enzyme to $65^{\circ} \mathrm{C}$ for $10 \mathrm{~min}$ destroyed most of the activity. The enzyme did not require ATP and $\mathbf{M g}^{2+}$ for activity. The enzyme could be stored at $-20^{\circ} \mathrm{C}$ in buffer containing $50 \%$ (vol/vol) glycerol and $500 \mu \mathrm{g}$ of bovine serum albumin per $\mathrm{ml}$ for at least 1 year without detectable loss of activity.

Since PBCV-1 DNA contains $1.9 \% \mathrm{~m}^{5} \mathrm{dC}$ and $1.5 \% \mathrm{~m}^{6} \mathrm{dA}$ (18), we determined whether the DNA methyltransferase

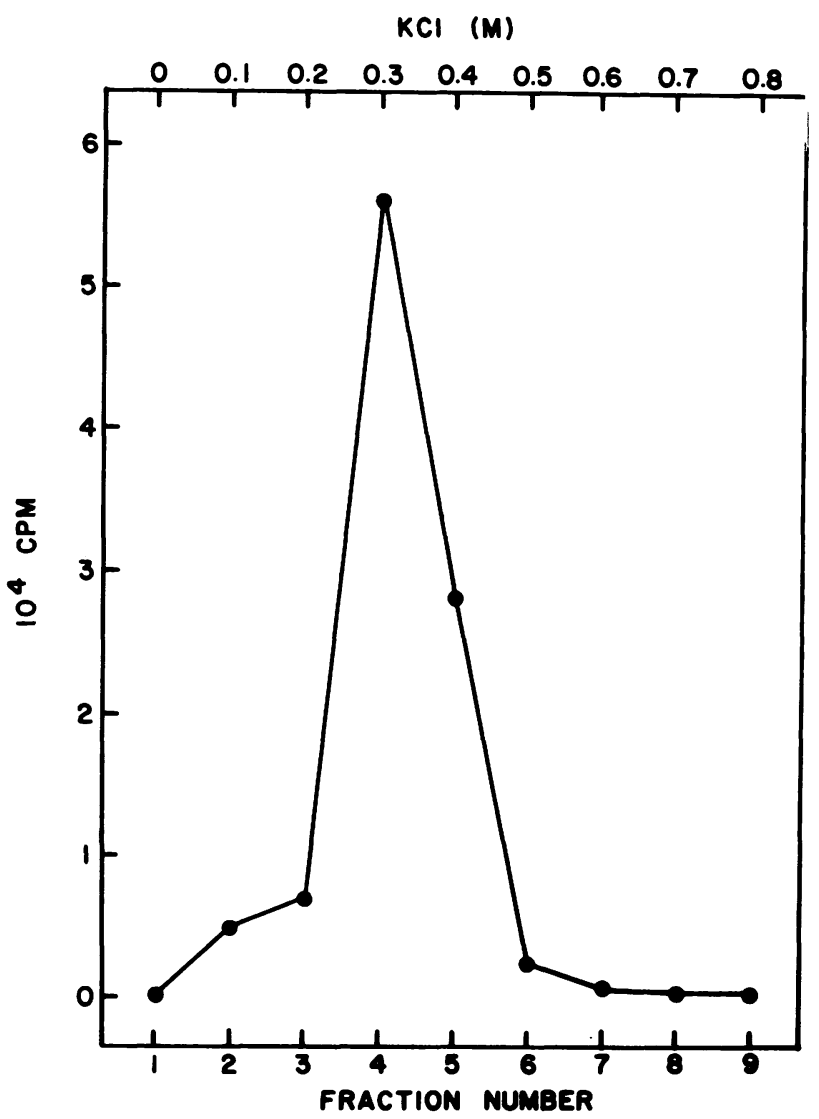

FIG. 1. Phosphocellulose column chromatography of an enzyme extract prepared from PBCV-1-infected Chlorella cells at $3 \mathrm{~h}$ postinfection. Protein $(33 \mathrm{mg})$ was applied to the column and eluted stepwise with 0 to $0.8 \mathrm{M} \mathrm{KCl}$. Fractions $(1 \mathrm{ml})$ were collected, and $10 \mu \mathrm{l}$ of the middle fraction at each salt concentration was assayed for DNA methyltransferase activity with $3 \mu \mathrm{g}$ of unmethylated lambda DNA as a substrate. 
methylates deoxycytosines or deoxyadenosines or both. Unmethylated lambda DNA was methylated with the fraction 2 enzyme extracted from 3-h-infected cells. This DNA was digested, and the resultant bases were analyzed by high-performance liquid chromatography. All of the radioactivity (ca. $40,000 \mathrm{cpm}$ ) eluted in the $\mathrm{m}^{6} \mathrm{dA}$ peak (data not shown). Therefore, this DNA methyltransferase has no methyldeoxycytosine activity and methylates only deoxyadenosine.

Column chromatography of DNA methyltransferase activity. An enzyme extract was prepared from 4 liters of cells at $3 \mathrm{~h}$ postinfection and chromatographed on a phosphocellulose column. The DNA methyltransferase activity eluted as a single peak from the column at 0.3 to $0.4 \mathrm{M} \mathrm{KCl}$ (Fig. 1). The PBCV-1-induced restriction endonuclease described in the preceding paper (22) eluted from the same column under the same conditions at 0.5 to $0.7 \mathrm{M} \mathrm{KCl}$. Thus, the methyltransferase activity can clearly be separated from the restriction endonuclease activity, i.e., two separate proteins are involved.

Abilities of various DNAs to serve as substrates. The abilities of various DNAs to serve as substrates for the PBCV-1-induced methyltransferase are reported in Table 2. The host Chlorella nuclear DNA, which contains about $21 \%$ $\mathrm{m}^{5} \mathrm{dC}$ and $0.6 \% \mathrm{~m}^{6} \mathrm{dA}$, was an excellent substrate for the virus-induced enzyme. In addition, both unmethylated lambda and pBR322 DNAs were good substrates for the enzyme. In contrast, PBCV-1 DNA was a poor substrate. To determine whether PBCV-1 DNA contained base sequences recognized by the enzyme, a BamHI fragment of PBCV-1 DNA (B6) was cloned into plasmid pBR322 (plasmid pLG164) and transformed into an E. coli dam dcm host, and the B6 insert DNA was isolated. After growth in this host the PBCV-1 DNA B6 fragment was an excellent substrate for the enzyme (Table 2). This indicates that PBCV-1 genomic DNA is modified in some way to make it inaccessible to the DNA methyltransferase.

DNAs isolated from other Chlorella viruses (16) differed in their abilities to serve as substrates for the enzyme. SC-1A, SC-1B, and NC-1A DNAs were poor substrates, whereas NC-1D, IL-2A, and IL-3A DNAs were good substrates (Table 2). There was a perfect correlation between the ability of these viral DNAs to serve as substrates for the PBCV-1induced DNA methyltransferase and their susceptibility to

TABLE 2. Substrate specificities of PBCV-1-induced DNA methyltransferase

\begin{tabular}{|c|c|}
\hline DNA substrate & $\begin{array}{c}\text { cpm of }\left[\text { methyl }-{ }^{3} \mathrm{H}\right] \mathrm{DNA} \\
\text { transferred } / 30 \mathrm{U} \text { of } \\
\text { enzyme }\end{array}$ \\
\hline $\begin{array}{l}\text { PBCV } 1 \ldots \ldots \ldots \ldots \ldots \ldots \\
\text { Unmethylated PBCV }-1 \text { Bam }{ }_{\text {HI }}\end{array}$ & 608 \\
\hline fragment $B 6 \ldots \ldots \ldots \ldots \ldots \ldots \ldots$ & 58,197 \\
\hline NC-1A virus. $\ldots \ldots \ldots \ldots \ldots \ldots \ldots \ldots$ & 1,165 \\
\hline NC-1D virus. $\ldots \ldots \ldots \ldots \ldots \ldots \ldots \ldots$ & 86,042 \\
\hline SC-1A virus $\ldots \ldots \ldots \ldots \ldots \ldots \ldots$ & 1,128 \\
\hline SC-1B virus $\ldots \ldots \ldots \ldots \ldots \ldots \ldots$ & 915 \\
\hline IL-2A virus $\ldots \ldots \ldots \ldots \ldots \ldots \ldots \ldots \ldots$ & 30,524 \\
\hline IL-3A virus $\ldots \ldots \ldots \ldots \ldots \ldots \ldots \ldots$ & 46,315 \\
\hline Chlorella strain NC64A nuclear. ......... & 113,326 \\
\hline Unmethylated lambda $\ldots \ldots \ldots \ldots \ldots \ldots$ & 75,119 \\
\hline Unmethylated pBR322............. & 118,860 \\
\hline
\end{tabular}

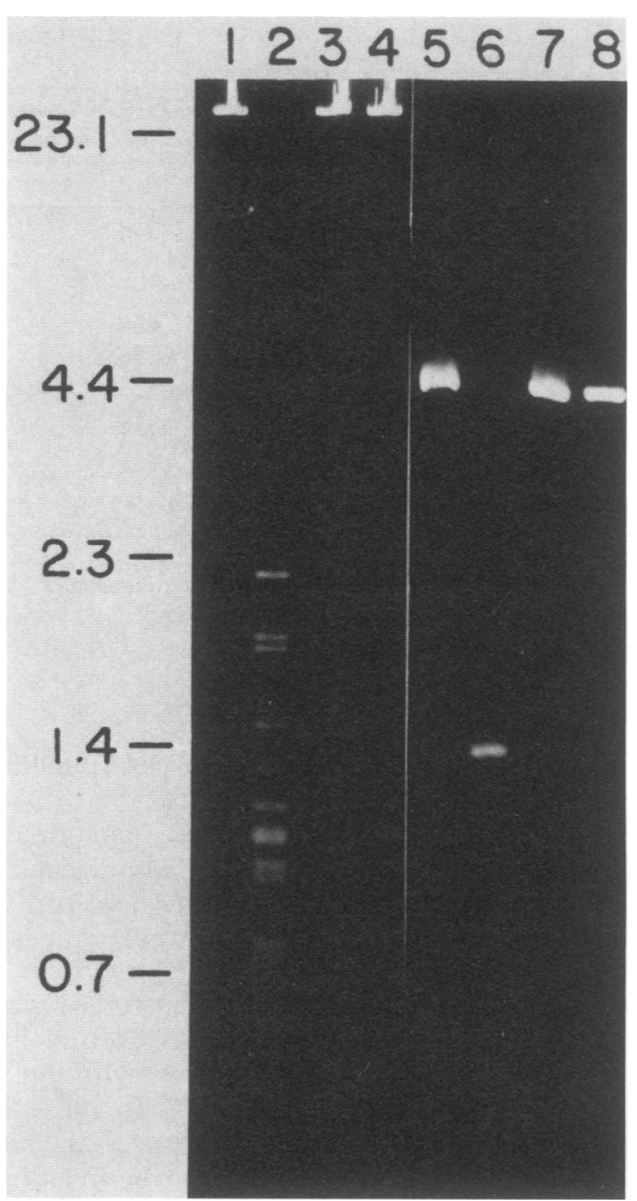

FIG. 2. Ability of PBCV-1-induced restriction endonuclease to cleave either lambda (lanes 1 to 4 ) or pBR322 (lanes 5 to 8) DNAs before or after incubating the DNAs with PBCV-1-induced DNA methyltransferase. Lanes 1,2 and 5, 6 contain unmethylated lambda and pBR322 DNA, respectively, and lanes 3, 4 and 7,8 contain lambda and pBR322 DNA, respectively, after incubation with the PBCV-1-induced DNA methyltransferase. DNAs in lanes 1, 3, 5, and 7 were not treated with restriction endonuclease, and DNAs in lanes $2,4,6$, and 8 were incubated with the PBCV-1-induced restriction endonuclease. Note: the majority of the pBR322 cleavage products in lane 6 have migrated off the gel. Numbers on left are in kilobase pairs.

the PBCV-1-induced restriction endonuclease; i.e., those DNAs that were susceptible to the PBCV-1-induced restriction endonuclease were good substrates for the PBCV-1induced DNA methyltransferase. Conversely, those viral DNAs that were not methylated by the DNA methyltransferase were resistant to the PBCV-1-induced restriction endonuclease (data not shown).

Protection against restriction endonucleases by methylation of DNA. We previously reported that PBCV-1 DNA but not host DNA contained $\mathrm{m}^{6} \mathrm{dA}$ in GATC sequences (18). Furthermore, PBCV-1 infection induces the synthesis of a restriction endonuclease which cleaves DNAs containing GATC, but not $\mathrm{G}^{\mathrm{m}} \mathrm{ATC}$, sequences (22). To determine whether the PBCV-1-induced methyltransferase could protect DNA from the PBCV-1-induced restriction endonuclease, unmethylated lambda and pBR322 DNAs were first methylated with the methyltransferase enzyme; these DNAs were then treated with the PBCV-1-induced restriction endonuclease. The PBCV-1-induced restriction endonuclease 


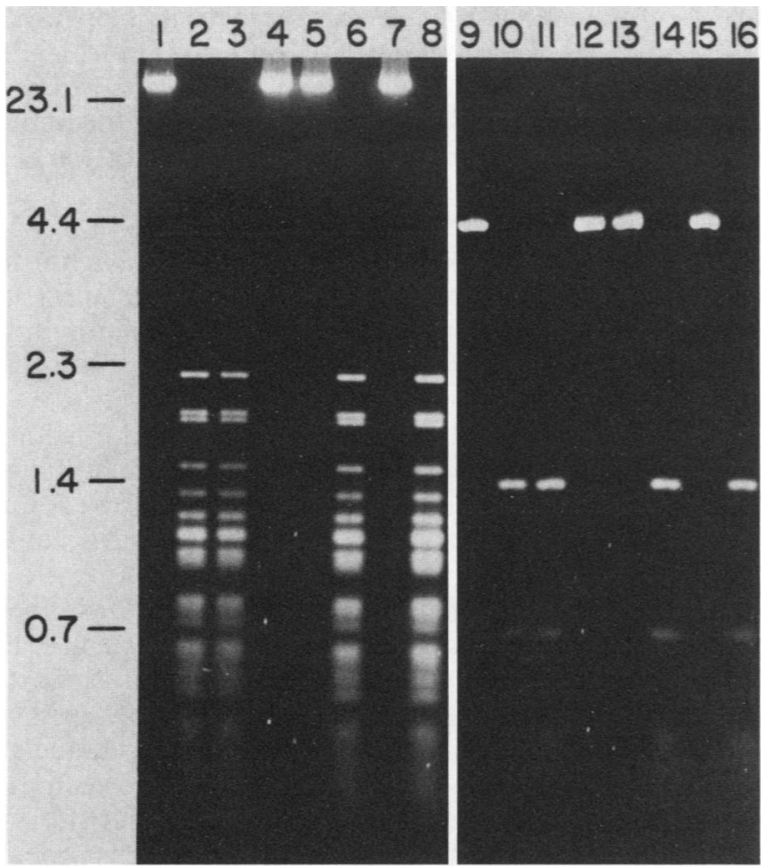

FIG. 3. Ability of MboI, DpnI, and Sau3AI to cleave either lambda (lanes 1 to 8) or pBR322 (lanes 9 to 16) DNAs before or after incubating the DNAs with PBCV-1-induced DNA methyltransferase. Lanes 1 to 4 and 9 to 12 contained unmethylated lambda and pBR322 DNA, respectively, and lanes 5 to 8 and 13 to 16 contained lambda and pBR322 DNA, respectively, after incubation with the DNA methyltransferase. DNAs in lanes $1,5,9$, and 13 were not treated with restriction endonuclease; DNAs in lanes $2,6,10$, and 14 were incubated with Sau3AI; DNAs in lanes 3, 7, 11, and 15 were incubated with $M b o \mathrm{I}$; and DNAs in lanes $4,8,12$, and 16 were incubated with DpnI. Numbers on left are in kilobase pairs.

digested both unmethylated DNAs (Fig. 2). However, both DNAs were resistant to the PBCV-1-induced restriction endonuclease if they were first methylated by the methyltransferase. That is, methylation of DNA by the virusinduced methyltransferases confers resistance to the virusinduced restriction endonuclease, probably by methylating deoxyadenosines in GATC sequences.

To verify methylation of deoxyadenosine in the GATC sequences, we also treated the methylated lambda and pBR322 DNAs from the preceding experiment with the restriction endonucleases MboI, Sau3AI, and DpnI. These three enzymes recognize the sequence GATC, but DpnI cleaves at this sequence only if the deoxyadenosine is methylated, whereas $\mathbf{M b o I}$ only cleaves at this sequence if the deoxyadenosine is not methylated. Sau3AI cleaves at this sequence irrespective of deoxyadenosine methylation. The unmethylated DNAs were digested with both Sau3AI and $M b o$ I but not with DpnI (Fig. 3). After methylation the DNAs were digested with Sau3AI and DpnI but not with MboI. Therefore, deoxyadenosine is methylated in the GATC sequence by the PBCV-1-induced methyltransferase.

Only deoxyadenosines in the GATC sequence are methylated. To determine whether the PBCV-1-induced DNA methyltransferase methylates deoxyadenosine at sequences in addition to GATC, we first incubated unmethylated lambda DNA with $E$. coli dam methylase or the PBCV-1induced DNA methyltransferase with unlabeled $S$ adenosylmethionine. dam methylase methylates deoxyadenosine solely in GATC sequences $(7,8,10)$. These methylated DNAs were isolated and incubated a second time with the PBCV-1-induced methyltransferase or dam methylase with labeled $S$-adenosylmethionine. Methylated DNAs were not further methylated by either enzyme (Table 3). Thus, the PBCV-1-induced methyltransferase and the dam methylase have identical sequence specificities.

Increased DNA methyltransferase activity requires de novo protein synthesis. To determine whether the increased methyltransferase activity obtained after PBCV-1 infection required de novo protein synthesis, we infected cells with PBCV-1, and cycloheximide was added either at the time of infection or at 30-min increments after infection; enzyme extracts were prepared from all of the cells at $3 \mathrm{~h}$ postinfection and assayed for DNA methyltransferase activity. The addition of cycloheximide at the same time as the virus prevented the increase in methyltransferase activity at $3 \mathrm{~h}$ postinfection (Table 4). The addition of cycloheximide at 30 and 60 min postinfection reduced the DNA methyltransferase activity; addition of cycloheximide at 90 and $120 \mathrm{~min}$ postinfection had little effect on methyltransferase activity at $3 \mathrm{~h}$. This indicates that the DNA methyltransferase is synthesized de novo early in infection.

DNA methyltransferase is probably virus encoded. To determine whether the methyltransferase was encoded by the viral genome, we prepared enzyme extracts from UVirradiated cells infected with PBCV-1 and assayed them for activity. PBCV-1 can replicate, albeit slowly, in such UVirradiated cells (J. Van Etten, D. Burbank, and R. Meints, submitted for publication). There was a steady increase in DNA methyltransferase activity over an 8-h period in the UV-irradiated infected cells (Table 5). Since endogenous host nucleic acid and protein syntheses are reduced to background levels in these cells (Van Etten et al., submitted for publication), the DNA methyltransferase is probably virus encoded.

\section{DISCUSSION}

This report demonstrates that PBCV-1 infection of Chlorella strain NC64A induces a DNA methyltransferase enzyme. The methylating activity eluted from a phosphocellulose column as a single peak and specifically methylated deoxyadenosines in GATC sequences. Procaryotic DNA methyltransferases are classified into three types according to their requirements for ATP (1). Since the

TABLE 3. Comparison of DNA methylation sites recognized by $E$. coli dam methylase and PBCV-1-induced DNA methyltransferase

\begin{tabular}{lcc}
\hline Enzyme used for DNA methylation & ${ }^{a}$ & $\begin{array}{c}\left.\text { cpm of [methyl }{ }^{3} \mathrm{H}\right] \mathrm{DNA} \\
\text { transferred } / 30 \text { U of enzyme }\end{array}$ \\
\hline Incubation 1 & Incubation 2 & 87,760 \\
None & dam $^{b}$ & 80,335 \\
None & PBCV-1 & 4,485 \\
dam & dam & 5,646 \\
dam & PBCV-1 & 2,398 \\
PBCV-1 & PBCV-1 & 2,091 \\
PBCV-1 & dam & \\
\hline
\end{tabular}

${ }^{a}$ Unmethylated lambda DNA served as the methyl group acceptor in incubation 1. Unlabeled $S$-adenosylmethionine and $S$-adenosyl[methyl${ }^{3} \mathrm{H}$ ]methionine were the methyl group donors for incubations 1 and 2 , respectively. After incubation 1 , the mixtures, including those with no enzyme, were heated at $65^{\circ} \mathrm{C}$ for $20 \mathrm{~min}$ and phenol extracted, and the DNA was precipitated with ethanol. These DNAs were used as substrates for the second reaction.

${ }^{b}$ dam, dam methylase.

' PBCV-1, PBCV-1-induced DNA methyltransferase (fraction 4). 
TABLE 4. Effect of cycloheximide addition at various times after PBCV-1 infection on DNA methyltransferase activity

\begin{tabular}{|c|c|c|c|}
\hline \multirow[t]{2}{*}{$\begin{array}{c}\left.\text { Time (min p.i. }{ }^{a}\right) \\
\text { cycloheximide }(25 \mu \mathrm{g} / \mathrm{ml}) \text { added }\end{array}$} & \multicolumn{3}{|c|}{$\begin{array}{c}\left.\text { cpm of [methyl- }{ }^{3} \mathrm{H}\right] \mathrm{DNA} \text { transferred } \\
10 \mu \text { of enzyme } e^{b} \text { after incubation } \\
\text { for: }\end{array}$} \\
\hline & $\mathbf{O h}$ & $1 \mathrm{~h}$ & $2 \mathrm{~h}$ \\
\hline $\begin{array}{l}\text { Uninfected cells } \\
\quad 0\end{array}$ & 90 & 190 & 504 \\
\hline $\begin{array}{c}\text { Infected cells } \\
0 \\
30 \\
60 \\
90 \\
120 \\
150\end{array}$ & $\begin{array}{r}60 \\
93 \\
137 \\
124 \\
161 \\
153\end{array}$ & $\begin{array}{r}149 \\
2,158 \\
12,418 \\
21,682 \\
28,836 \\
29,124\end{array}$ & $\begin{array}{r}197 \\
5,211 \\
35,038 \\
60,438 \\
77,020 \\
76,128\end{array}$ \\
\hline None added & 210 & 29,356 & 81,098 \\
\hline
\end{tabular}

${ }^{a}$ p.i., Postinfection.

${ }^{b}$ Enzyme extracts (fraction 2) were prepared from an equal number of uninfected or PBCV-1-infected cells at $3 \mathrm{~h}$ postinfection. Reaction mixtures $(50 \mu \mathrm{l})$ containing $2 \mu \mathrm{Ci}$ of $S$-adenosyl $\left[\right.$ methyl $\left.{ }^{3} \mathrm{H}\right]$ methionine, $3 \mu \mathrm{g}$ of unmethylated lambda DNA, and $10 \mu \mathrm{l}$ of enzyme extract were incubated at $37^{\circ} \mathrm{C}$ for the indicated times.

PECV-1-induced DNA methytransferase does not require ATP for activity, it resembles type II methylases. DNA methyltransferases are also classified as maintenance or de novo enzymes depending on their preference for either hemimethylated DNA or totally unmethylated DNA (6). Since the PBCV-1-induced methyltransferase methylated unmethylated DNAs extensively, we believe it is a de novo type.

The PBCV-1-induced DNA methyltransferase activity first appears between 30 and 60 min postinfection, and its appearance requires de novo protein synthesis. Thus, the appearance of the DNA methyltransferase coincides with the initiation of PBCV-1 DNA synthesis which begins at about 45 min postinfection (15). Since PBCV-1 DNA contains $\mathrm{G}^{\mathrm{m}} \mathrm{ATC}$ sequences (16), we believe the methyltransferase is responsible for this methylation.

In all probability the PBCV-1-induced DNA methyltrans-

TABLE 5. DNA methyltransferase activity from UV-irradiated Chlorella cells infected with PBCV-1

\begin{tabular}{lrrr}
\hline & \multicolumn{3}{c}{ cpm of $\left[\right.$ methyl $^{3} \mathrm{H}$ H]DNA transferred/ } \\
Enzyme extracts from: & \multicolumn{3}{c}{$10 \mu$ of enzyme ${ }^{a}$ after incubation for: } \\
\cline { 2 - 4 } & $0 \mathrm{~h}$ & $1 \mathrm{~h}$ & $2 \mathrm{~h}$ \\
\hline Uninfected cells (h) & 103 & 480 & 680 \\
0 & 74 & 277 & 308 \\
4 & 112 & 589 & 535 \\
8 & & & \\
& & & \\
Infected cells (h p.i. $\left.{ }^{b}\right)$ & 119 & 682 & 695 \\
0 & 65 & 9,851 & 13,239 \\
2 & 201 & 49,666 & 65,939 \\
4 & 236 & 58,198 & 79,730 \\
6 & 188 & 65,946 & 82,150 \\
8 & &
\end{tabular}

a Enzyme extracts (fraction 2) were prepared from an equal number of uninfected or PBCV-1-infected UV-irradiated Chlorella cells at the indicated times. Reaction mixtures $(50 \mu \mathrm{l})$ containing $2 \mu \mathrm{Ci}$ of $S$-adenosyl[methyl${ }^{3} \mathrm{H}$ ]methionine, $3 \mu \mathrm{g}$ of unmethylated lambda DNA, and $10 \mu \mathrm{l}$ of enzyme extract were incubated at $37^{\circ} \mathrm{C}$ for the indicated times.

b p.i., Postinfection. ferase is virus encoded since enzyme activity appeared in PBCV-1-infected UV-irradiated Chlorella cells in which host DNA, RNA, and protein syntheses were reduced to about background levels (Van Etten et al., submitted for publication). However, definitive proof requires identification of the methyltransferase gene.

To our knowledge the only previous report of a virusencoded DNA methyltransferase in a eucaryotic organism is in frog virus 3 (20). Frog virus 3 infection of fathead minnow cells leads to the appearance of a de novo DNA methyltransferase. The frog virus 3-induced enzyme methylates deoxycytosines in the dinucleotide sequence C-G.

Since PBCV-1 DNA also contains $1.9 \% \mathrm{~m}^{5} \mathrm{dC}$ in addition to $1.5 \% \mathrm{~m}^{6} \mathrm{dA}(18)$ we suspect that PBCV-1 infection also induces a unique cytosine methyltransferase. However, under our conditions no cytosine methyltransferase activity was detected.

This paper and the preceding paper, which describes a PBCV-1-induced restriction endonuclease (22), suggest how PBCV-1 DNA is protected during infection and replication while host DNA is concurrently degraded (15). Both the DNA methyltransferase and the restriction endonuclease recognize the same base sequence, GATC. The restriction endonuclease cleaves host GATC sequences but not viral $\mathrm{G}^{\mathrm{m}} \mathrm{ATC}$ sequences. The DNA methyltransferase is probably responsible for methylating deoxyadenosines in the viral DNA.

There are at least two explanations why the PBCV-1induced DNA methyltransferase does not methylate the host DNA in vivo. PBCV-1 DNA might replicate in the cytoplasm, whereas host DNA replicates in the nucleus. If so, the PBCV-1-induced restriction endonuclease but not the DNA methyltransferase would have to be transported into the nucleus. At present we have no information on the cellular location of PBCV-1 DNA synthesis. Alternatively, the methyltransferase enzyme might specifically associate with viral DNA.

In summary, the virus PBCV-1 apparently encodes a modification-restriction system which resembles those of bacteria $(2,12,13)$. However, in bacteria the systems are typically encoded by the host, whereas the present system is probably virus encoded and associated with a eucaryotic organism.

\section{ACKNOWLEDGMENTS}

We thank Stan Hattman and David Swinton for performing the DNA base analysis, Martin Marinus for providing E. coli GM2163, and Lois Girton for providing plasmid pLG164. The helpful discussions with Russel Meints, Les Lane, and Myron Brakke are gratefully acknowledged.

This investigation was supported, in part, by Public Health Service grant GM-32441 from the National Institute of General Medical Sciences and grant DE-AC02-82ER12086 from the Department of Energy.

\section{LITERATURE CITED}

1. Adams, R. L. P., and R. H. Burdon. 1983. DNA methylases, p. 119-144. In S. T. Jacob (ed.), Enzymes of nucleic acid synthesis and modification, vol. 1. DNA enzymes. CRC Press, Inc., Boca Raton, Fla.

2. Boyer, H. W. 1971. DNA restriction and modification mechanism in bacteria. Annu. Rev. Microbiol. 25:153-176.

3. Burnett, T. S., and J. P. Sleeman. 1984. Uneven distribution of methylation sites within the human papillomavirus la genome: possible relevance to viral gene expression. Nucleic Acids Res. 12:8847-8860. 
4. Danos, O., M. Katinka, and M. Yaniv. 1980. Molecular cloning, refined physical map and heterogeneity of methylation sites of papilloma virus type 1a DNA. Eur. J. Biochem. 109:457-461.

5. Doerfler, W. 1981. DNA methylation-a regulatory signal in eukaryotic gene expression. J. Gen. Virol. 57:1-20.

6. Doerfler, W. 1983. DNA methylation and gene activity. Annu. Rev. Biochem. 52:93-124.

7. Geier, G. E., and P. Modrich. 1979. Recognition sequence of the dam methylase of $E$. coli $\mathrm{K} 12$ and mode of $D p n I$ endonuclease. J. Biol. Chem. 254:1408-1413.

8. Hattman, S., J. E. Brooks, and M. Masurekar. 1978. Sequence specificity of the P1-modification methylase (M. EcoPI) and the DNA methylase (M. Ecodam) controlled by the E. coli dam gene. J. Mol. Biol. 126:367-380.

9. Jones, P. A., and S. Taylor. 1981. Hemimethylated duplex DNAs prepared from 5-azacytidine-treated cells. Nucleic Acids Res. 9:2933-2947.

10. Lacks, S., and B. Greenberg. 1977. Complementary specificity of restriction endonucleases of Diplococcus pneumoniae with respect to DNA methylation. J. Mol. Biol. 114:153-168.

11. Marinus, M. G., M. Carraway, A. Z. Frey, L. Brown, and J. A. Arraj. 1983. Insertion mutations in the dam gene of Escherichia coli K-12. Mol. Gen. Genet. 192:288-289.

12. Modrich, P. 1979. Structure and mechanisms of DNA restriction and modification enzymes. Q. Rev. Biophys. 12:315-369.

13. Modrich, P., and R. J. Roberts. 1982. Type II restriction and modification enzymes, p. 109-154. In S. M. Linn and R. J. Roberts (ed.), Nucleases. Cold Spring Harbor Laboratory, Cold
Spring Harbor, N.Y.

14. Profitt, J. H., J. R. Davie, D. Swinton, and S. Hattman. 1984. 5-Methylcytosine is not detectable in Saccharomyces cerevisiae DNA. Mol. Cell. Biol. 4:985-987.

15. Van Etten, J. L., D. E. Burbank, J. Joshi, and R. H. Meints. 1984. DNA synthesis in a Chlorella-like alga following infection with the virus PBCV-1. Virology 134:443-449.

16. Van Etten, J. L., D. E. Burbank, A. M. Schuster, and R. H. Meints. 1985. Lytic viruses infecting a Chlorella-like alga. Virology 140:135-143.

17. Van Etten, J. L., D. E. Burbank, Y. Xia, and R. H. Meints. 1983. Growth cycle of a virus, PBCV-1, that infects Chlorella-like algae. Virology 126:117-125.

18. Van Etten, J. L., A. M. Schuster, L. Girton, D. E. Burbank, D. Swinton, and S. Hattman. 1985. DNA methylation of viruses infecting a eukaryotic Chlorella-like green alga. Nucleic Acids Res. 13:3471-3478.

19. Wagner, H., D. Simon, E. Werner, H. Gelderblom, C. Darai, and R. M. Flugel. 1985. Methylation pattern of fish lymphocystis disease virus DNA. J. Virol. 53:1005-1007.

20. Willis, D. B., R. Goorha, and A. Granoff. 1984. DNA methyltransferase induced by frog virus 3. J. Virol. 49:86-91.

21. Willis, D. B., and A. Granoff. 1980. Frog virus 3 is heavily methylated at $\mathrm{CpG}$ sequences. Virology 107:250-257.

22. Xia, Y., D. E. Burbank, L. Uher, D. Rabussay, and J. L. Van Etten. 1986. Restriction endonuclease activity induced by PBCV-1 infection of a Chlorella-like green alga. Mol. Cell. Biol. 6:1430-1439. 